\title{
Cultural and morphological characterization of rhizospheric isolates of fungal antagonist Trichoderma
}

\author{
K. K. Sharma ${ }^{1 *}$ and U. S. Singh ${ }^{2}$ \\ ${ }^{1}$ Vivekanand Parvatiya Krishi Anusandhan Sansthan, Almora-263601 (Uttarakhand), INDIA \\ ${ }^{2}$ International Rice Research Institute - 9th Floor, Aggarwal Corporate Tower, Rajendra Place, New Delhi - 110 008, INDIA \\ *Corresponding author. E-mail: abhay23p@yahoo.com
}

Received: April 02, 2014, Revised received: August 22, 2014 Accepted: October 05, 2014

\begin{abstract}
The genus Trichoderma contains species that are of a great economic importance due to their ability to act as biological control agents against a large variety of fungal plant pathogens. In the present investigation thirty isolates of the Trichoderma sp. were obtained from the rhizosphere soils of different plants at different locations at Nainital, Almora, Udham Singh Nagar, Derhadun, Haridwar and Tehri Garhwal districts of Uttarakhand (India). The isolates were characterized on the basis of their cultural and morphological characteristics. The cultural characteristics included linear growth, colony colour, pigmentation and growth pattern. Morphological characteristics studied were structure, shape and arrangement of conidiophores, phialides and conidia. Out of thirty isolates, 6 isolates namely PB10, PB13, PB23, PB26, PB27 and PB28 were identified as T. virens and remaining 24 isolates as T. harzianum.
\end{abstract}

Keywords: Characterization, Cultural, Morphological, Phialides, Trichoderma

\section{INTRODUCTION}

Genus Trichoderma have traditionally been classified as Fungi Imperfecti based upon differences in morphology under Deuteromycotina, Hyphomycetes, Phialasporace, Hyphales, Dematiaceae as they produce only asexual spores i.e. conidia (Singh et al., 2006). As is usually the case with other fungal genera, species of Trichoderma too were defined originally on the basis of morphology by workers like Rifai (1969) and Bisset (1991a, b and c). The culture sporulation pattern varied considerably within and between the two species. Although conidial shape and arrangement and hyphal branching pattern helped in distinguishing species from each other, they failed to designate Trichoderma species. Seaby (1996) also reported that differentiation of Trichoderma spp. using classical microscopic features alone was difficult since cultural morphology varied widely on different media and spore size varied significantly with incubation temperature. Moreover, variation among the isolates based on size of the phialides, and their arrangements was small. However, sporulation pattern and size of the spores within the species were highly variable. Keeping the above facts in view, the present study was undertaken to characterize and estimate cultural and morphological variability among thirty isolates of Trichoderma isolated from the rhizospheric soil of different crops and locations of Uttarakhand.

\section{MATERIALS AND METHODS}

Sampling and isolation: The experimental material consisted of the thirty strains of the Trichoderma sp. which were isolated from the rhizospheric soil samples on Trichoderma selective medium (Elad et al., 1981) using serial dilution technique (Krassilnikov, 1950) from different crops and locations of Nainital, Almora, Udham Singh Nagar, Derhadun, Haridwar and Tehri Garhwal districts of Uttarakhand-India (Table 1).

Cultural and morphological characterization of Trichoderma isolates: The cultural and morphological characteristics of the 30 Trichoderma isolates were determined on Potato dextrose agar (PDA) and Cornmeal dextrose agar (CMD) medium respectively. A $5 \mathrm{~mm}$ diameter disc using a sterile cork borer was cut from the actively growing edge of a fresh colony (before the start of conidial production) placed on Petri dish containing $20 \mathrm{ml}$ medium (PDA for cultural and CMD for morphological study) approximately $1.5 \mathrm{~cm}$ from the edge of the Petri dish with the mycelial surface facing downwards and three replications were maintained for each isolate.

For cultural study, one set of Petri dishes were incubated at $25^{\circ} \mathrm{C}$ and another set at $35^{\circ} \mathrm{C}$ in darkness. The colonies were examined at $24 \mathrm{~h}$ intervals for pattern of conidiation, first appearance of green conidia, formation of conidial pustules, presence of any odor or yellow pigmentation and colony radius was measured from the edge of the inoculum plug after $72 \mathrm{~h}$ at both $25^{\circ} \mathrm{C}$ and $35^{\circ} \mathrm{C}$. For morphological characterization of Trichoderma, the cultures were incubated at $20^{\circ} \mathrm{C}$. Microscopic preparations for morphological studies slides were prepared in $3 \%$ 
$\mathrm{KOH}$ followed by lactophenol-cotton blue from pustules where conidia were still white, generally within a week of incubation at $20^{\circ} \mathrm{C}$. After placing the cover slip, the slide was observed under the microscope for morphological characters like conidiophores, their branching pattern, angle to main axis, phialide numbers and their arrangement, conidial shape and colour and formation of chlamydospores and their position. Species identification was based on the morphological and taxonomic keys provided by Bisset (1991a, b).

\section{RESULTS}

Cultural characterization of Trichoderma isolates: The cultural characteristics and growth rates of the 30 Trichoderma isolates were determined on Potato dextrose agar medium (Table 2). All the isolates were fast growing reaching a radius of 42.5 to $56.5 \mathrm{~mm}$ after 72 $\mathrm{h}$ at $25^{\circ} \mathrm{C}$ and 20 to $37.8 \mathrm{~mm}$ after $72 \mathrm{~h}$ at $35^{\circ} \mathrm{C}$. At $35^{\circ} \mathrm{C}$, the isolates produced abnormal compact colonies with irregular margin. Conidiation in the T. harzianum isolates was predominantly effuse covering the entire surface of the plates. However, some isolates initially produced flat pustules in concentric rings. The pustules appeared powdery due to dense conidiation. T. virens isolates showed predominantly effuse conidiation without formation of any pustule. Some isolates produced yellow pigment on PDA. Conidial colour change was observed from white to varying shades of green. In most isolates conidia were formed by $48 \mathrm{~h}$ and turned green within $72 \mathrm{~h}$.

Morphological characterization of Trichoderma isolates: In the morphological studies of Trichoderma, primarily two types of arrangement of conidiophores and phialides was observed among the 30 isolates (Plates 1, 2, Table 3). Twenty four isolates except PB 10, 13, 23, 26, 27 and 28 were characterized by highly branched divergent and dendritic conidiophores. Longest branches form near the base of the hypha and nearest the main axis. Branches toward the tip and secondary branches tended to be held at $90^{\circ}$ with respect to the axis from which they arise. Cells supported the phialides equivalent in width to, or at most only slightly wider than, the base of phialides arising from them. Divergent phialides were typically arranged in whorls of 3-5 and held at $90^{\circ}$ with respect to the hyphae from which they arose, or solitary. Those in whorls were typically flask-shaped, enlarged in the

Table1. Soil samples collected from different locations of Uttarakhand.

\begin{tabular}{|c|c|c|c|c|c|}
\hline L. No. & Sample code & Crop & Location & Soil pH & Isolate code \\
\hline 1 & $\mathrm{R} 1 \mathrm{KG}$ & Rice & Kathgodam-Haldwani & 6.9 & PB1 \\
\hline 2 & $\mathrm{R} 3 \mathrm{H}$ & Rice & Halduchaur-Haldwani & 6.8 & PB2 \\
\hline 3 & $\mathrm{R} 2 \mathrm{LCb}$ & Rice & Lamachaur-Haldwani & 7.0 & PB3 \\
\hline 4 & R1Da & Rice & Kherna-Almora & 6.9 & PB4 \\
\hline 5 & $\mathrm{R} 1 \mathrm{Db}$ & Rice & Kherna-Almora & 6.8 & PB5 \\
\hline 6 & $\mathrm{R} 2 \mathrm{Da}$ & Rice & Kherna-Almora & 7.0 & PB6 \\
\hline 7 & $\mathrm{R} 2 \mathrm{Db}$ & Rice & Kherna-Almora & 7.0 & PB7 \\
\hline 8 & SPC1 & Rice & SPC-Pantnagar & 6.8 & PB8 \\
\hline 9 & $\mathrm{SPC} 2$ & Rice & SPC-Pantnagar & 6.8 & PB9 \\
\hline 10 & $1 \mathrm{a}$ & Rice & Rudrapur-U.S. Nagar & 7.2 & PB 10 \\
\hline 11 & $1 \mathrm{ab}$ & Rice & Rudrapur-U.S. Nagar & 7.2 & PB11 \\
\hline 12 & $1 b c$ & Rice & Rudrapur-U.S. Nagar & 7.2 & PB 12 \\
\hline 13 & 3 & Rice & Rudrapur-U.S. Nagar & 7.1 & PB13 \\
\hline 14 & 5 & Rice & Rudrapur-U.S. Nagar & 7.1 & PB 14 \\
\hline 15 & AM & Apple & Mukteshwar-Almora & 6.7 & PB 15 \\
\hline 16 & $\mathrm{BM}$ & Broccoli & Mukteshwar-Almora & 6.8 & PB 16 \\
\hline 17 & PM1 & Pea & Mukteshwar-Almora & 6.8 & PB 17 \\
\hline 18 & PM2 & Pea & Mukteshwar-Almora & 6.8 & PB 18 \\
\hline 19 & SM & Strawberry & Mukteshwar-Almora & 6.8 & PB19 \\
\hline 20 & WM & Walnut & Mukteshwar-Almora & 6.8 & PB20 \\
\hline 21 & RP1 & Rice & Premnagar-Dehradun & 6.6 & PB21 \\
\hline 22 & TR1 & Mustard & Premnagar-Dehradun & 6.7 & PB22 \\
\hline 23 & A & Maize & Dhalwala-Rishikesh & 6.8 & PB23 \\
\hline 24 & $\mathrm{~B}$ & Maize & Bhaniawala-Dehradun & 7.0 & PB24 \\
\hline 25 & B1 & Rice & Bhaniawala-Dehradun & 7.1 & PB25 \\
\hline 26 & $\mathrm{C} 1$ & Rice & Mazra-Ranipokhri & 6.9 & PB26 \\
\hline 27 & $\mathrm{D}$ & Maize & Geetanagar Rishikesh & 6.8 & PB27 \\
\hline 28 & D1 & Rice & Raipur-Dehradun & 6.8 & PB28 \\
\hline 29 & $\mathrm{~F} 1$ & Rice & Raiwala-Hardwar & 7.1 & PB29 \\
\hline 30 & G1 & Rice & Nagani, Tehri Garhwal & 7.0 & PB30 \\
\hline
\end{tabular}


Table 2. Cultural characteristics of different Trichoderma isolates.

\begin{tabular}{|c|c|c|c|c|c|c|c|}
\hline $\begin{array}{c}\text { Sample } \\
\text { code }\end{array}$ & $\begin{array}{l}\text { Isolate } \\
\text { code }\end{array}$ & $\begin{array}{c}\begin{array}{c}\text { Colony } \\
\text { growth }\end{array} \\
(\mathbf{m m}) \text { after } \\
72 \text { hrs at } \\
25^{\circ} \mathrm{C} \\
\end{array}$ & $\begin{array}{c}\text { Colony } \\
\text { Growth } \\
(\mathbf{m m}) \text { After } \\
72 \text { hrs at } \\
3^{\circ} \mathrm{C}\end{array}$ & $\begin{array}{l}\text { Culture } \\
\text { Colour }\end{array}$ & $\begin{array}{c}\text { Conidiation } \\
\text { E/F (Effuse/ } \\
\text { flat } \\
\text { pustule) }\end{array}$ & Pigmentation & $\begin{array}{l}\text { Sporulation } \\
\text { initiate } \\
\text { After (hrs) }\end{array}$ \\
\hline $\mathrm{R} 1 \mathrm{KG}$ & PB1 & 50.5 & 32.4 & Dark green & $\mathrm{E}$ & $\begin{array}{c}\text { Brownish } \\
\text { yellow }\end{array}$ & 48 \\
\hline $\mathrm{R} 3 \mathrm{H}$ & PB2 & 51.3 & 34.0 & Light Green & $\mathrm{E}+\mathrm{F}$ & - & 36 \\
\hline $\mathrm{R} 2 \mathrm{LC}$ & PB3 & 52.5 & 35.6 & Dark green & $\mathrm{E}$ & $\begin{array}{l}\text { Brownish } \\
\text { yellow }\end{array}$ & 48 \\
\hline $\mathrm{R} 1 \mathrm{Da}$ & PB4 & 53.5 & 32.7 & Whitish green & $\mathrm{E}$ & - & 72 \\
\hline $\mathrm{R} 1 \mathrm{Db}$ & PB5 & 56.0 & 31.4 & Whitish green & $E+F$ & - & 48 \\
\hline $\mathrm{R} 2 \mathrm{Da}$ & PB6 & 55.5 & 31.0 & Whitish green & $E+F$ & - & 48 \\
\hline $\mathrm{R} 2 \mathrm{Db}$ & PB7 & 52.5 & 33.0 & Light Green & $\mathrm{E}$ & - & 48 \\
\hline SPC1 & PB8 & 56.0 & 36.0 & Dark green & $\mathrm{E}+\mathrm{F}$ & - & 48 \\
\hline SPC2 & PB9 & 52.5 & 35.5 & Dark green & $\mathrm{E}+\mathrm{F}$ & - & 48 \\
\hline $1 \mathrm{a}$ & PB10 & 50.6 & 27 & Light Green & $\mathrm{E}$ & Yellow & $48-72$ \\
\hline $1 \mathrm{ab}$ & PB11 & 50.4 & 32.9 & $\begin{array}{l}\text { Yellowish } \\
\text { green }\end{array}$ & $\mathrm{E}$ & Yellow & $48-72$ \\
\hline $1 b c$ & PB12 & 42.5 & 20 & Dark green & $\mathrm{E}$ & - & $48-72$ \\
\hline 3 & PB13 & 50.5 & 36.0 & Whitish green & $\mathrm{E}$ & - & 72 \\
\hline 5 & PB14 & 52.5 & 34.2 & Whitish green & $\mathrm{E}$ & - & $48-72$ \\
\hline $\mathrm{AM}$ & PB15 & 56.5 & 37.8 & Dark green & $\mathrm{E}$ & - & 48 \\
\hline $\mathrm{BM}$ & PB16 & 53.0 & 35.1 & Whitish green & $\mathrm{F}$ & - & 72 \\
\hline PM1 & PB17 & 54.1 & 32.3 & Dark green & $\mathrm{E}+\mathrm{F}$ & Yellow & 48 \\
\hline PM2 & PB18 & 55.0 & 34.2 & Dark green & $\mathrm{E}$ & - & 48 \\
\hline SM & PB19 & 55.5 & 35.6 & Dark green & $\mathrm{E}$ & - & 48 \\
\hline WM & PB20 & 46.5 & 28.4 & Whitish green & $\mathrm{F}$ & - & 72 \\
\hline RP1 & PB21 & 52.5 & 33.7 & Dark green & $\mathrm{E}+\mathrm{F}$ & - & 48 \\
\hline TR1 & PB22 & 51.5 & 32.6 & $\begin{array}{l}\text { Yellowish } \\
\text { green }\end{array}$ & $\mathrm{E}$ & Yellow & $48-72$ \\
\hline A & PB23 & 50.5 & 31.6 & Light Green & $\mathrm{E}$ & Yellow & 72 \\
\hline B & PB24 & 52.5 & 34.7 & Light Green & $\mathrm{E}$ & - & 48 \\
\hline B1 & PB25 & 53.5 & 34.0 & Dark green & $\mathrm{E}$ & - & 48 \\
\hline $\mathrm{C} 1$ & PB26 & 51.5 & 33.5 & Whitish green & $\mathrm{E}$ & Yellow & 48 \\
\hline $\mathrm{D}$ & PB27 & 50.3 & 34.5 & $\begin{array}{l}\text { Yellowish } \\
\text { green }\end{array}$ & $\mathrm{E}$ & Yellow & 48 \\
\hline D1 & PB28 & 53.5 & 35.0 & Dark green & $\mathrm{E}$ & - & 72 \\
\hline $\mathrm{F} 1$ & PB29 & 52.5 & 33.0 & Light Green & $\mathrm{F}$ & $\begin{array}{l}\text { Yellowish } \\
\text { brown }\end{array}$ & 48 \\
\hline G1 & PB30 & 50.3 & 30.7 & Whitish green & $\mathrm{F}$ & - & $48-72$ \\
\hline
\end{tabular}

middle, sharply constricted below the tip to form a narrow neck and slightly constricted at the base. Terminal phialides in a whorl or solitary, were typically cylindrical or at least not conspicuously swollen in the middle and longer than the subterminal phialides (Plate 1). These above characteristics resembled with Trichoderma harzianum. The remaining 6 isolates (PB
10, 13, 23, 26, 27 and 28) exhibited hyaline conidiophores arising in clusters from aerial mycelium, branching toward the tip, each branch terminating in a penicillus of 3-6 closely appressed and divergently branched phialides towards the apex, with a sterile stipe (Plate 2). The characteristics of these isolates typically resembled with $T$. virens. 


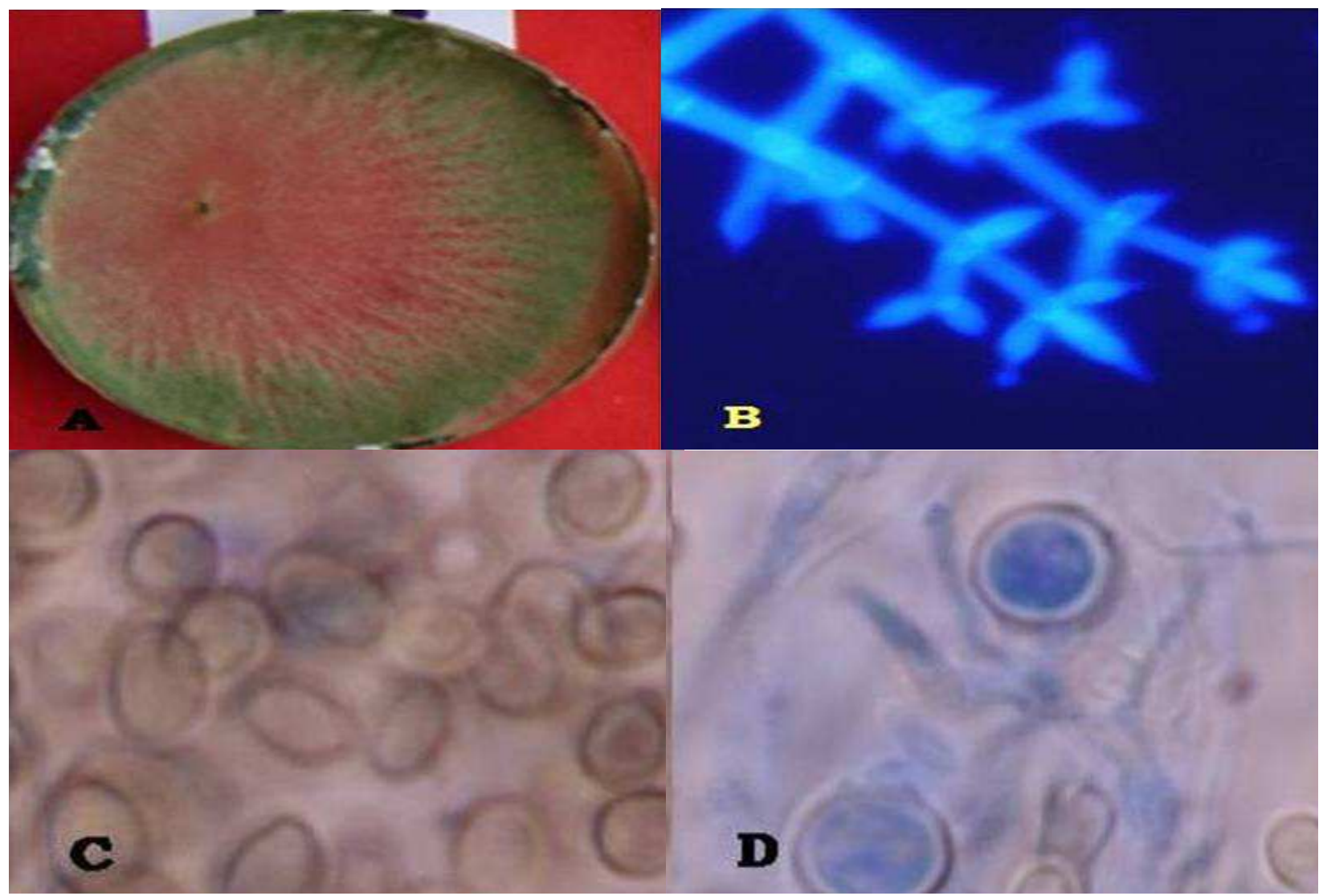

Plate 1. Isolate PB2. Trichoderma harzianum; A. Culture B. Conidiophore and Phialides C. Conidia D. Chlamydospores
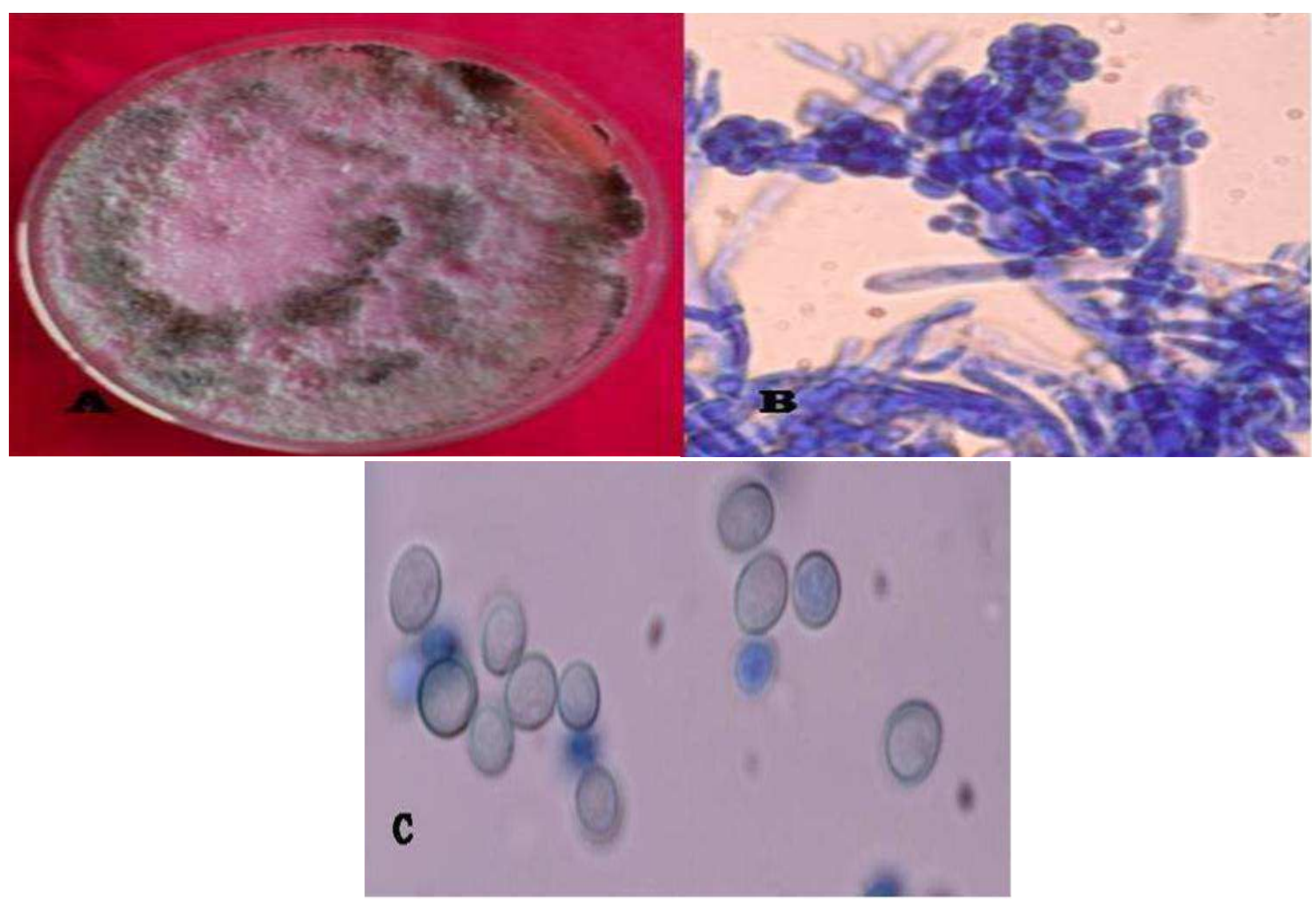

Plate 2. Isolate PB 23. Trichoderma virens A. culture, B. Conidiophore and phialides $C$. Conidia 
Table 3. Morphological characteristics of Trichoderma isolates.

\begin{tabular}{|c|c|c|c|c|c|c|c|}
\hline $\begin{array}{l}\text { S. } \\
\text { No. }\end{array}$ & $\begin{array}{l}\text { Isolate } \\
\text { code }\end{array}$ & $\begin{array}{c}\text { Divergently } \\
\text { Branched } \\
\text { conidiophore } \\
\text { at } 90^{\circ}\end{array}$ & $\begin{array}{c}\text { Clutered } \\
\text { conidiophore } \\
\text { terminating } \\
\text { with } \\
\text { penicullus }\end{array}$ & $\begin{array}{c}\text { Divergently } \\
\text { branched } \\
\text { phiallids with } \\
\text { fertile apex }\end{array}$ & $\begin{array}{c}\text { Closely } \\
\text { appressed } \\
\text { phiallids } \\
\text { with sterile } \\
\text { stipe }\end{array}$ & Chlamydospore & $\begin{array}{l}\text { T. harzianum } \\
\text { / T. virens }\end{array}$ \\
\hline 1 & PB 1 & $\sqrt{ }$ & - & $\sqrt{ }$ & - & $\sqrt{ }$ & T. harzianum \\
\hline 2 & PB 2 & $\sqrt{ }$ & - & $\sqrt{ }$ & - & $\sqrt{ }$ & T. harzianum \\
\hline 3 & PB 3 & $\sqrt{ }$ & - & $\sqrt{ }$ & - & $\sqrt{ }$ & T. harzianum \\
\hline 4 & PB 4 & $\sqrt{ }$ & - & $\sqrt{ }$ & - & $\sqrt{ }$ & T. harzianum \\
\hline 5 & PB 5 & $\sqrt{ }$ & - & $\sqrt{ }$ & - & - & T. harzianum \\
\hline 6 & PB 6 & $\sqrt{ }$ & - & $\sqrt{ }$ & - & $\sqrt{ }$ & T. harzianum \\
\hline 7 & PB 7 & $\sqrt{ }$ & - & $\sqrt{ }$ & - & $\sqrt{ }$ & T. harzianum \\
\hline 8 & PB 8 & $\sqrt{ }$ & - & $\sqrt{ }$ & - & $\sqrt{ }$ & T. harzianum \\
\hline 9 & PB 9 & $\sqrt{ }$ & - & $\sqrt{ }$ & - & $\sqrt{ }$ & T. harzianum \\
\hline 10 & PB 11 & $\sqrt{ }$ & - & $\sqrt{ }$ & - & $\sqrt{ }$ & T. harzianum \\
\hline 11 & PB 12 & $\sqrt{ }$ & - & $\sqrt{ }$ & - & $\sqrt{ }$ & T. harzianum \\
\hline 12 & PB 14 & $\sqrt{ }$ & - & $\sqrt{ }$ & - & $\sqrt{ }$ & T. harzianum \\
\hline 13 & PB 15 & $\sqrt{ }$ & - & $\sqrt{ }$ & - & $\sqrt{ }$ & T. harzianum \\
\hline 14 & PB 16 & $\sqrt{ }$ & - & $\sqrt{ }$ & - & - & T. harzianum \\
\hline 15 & PB 17 & $\sqrt{ }$ & - & $\sqrt{ }$ & - & $\sqrt{ }$ & T. harzianum \\
\hline 16 & PB 18 & $\sqrt{ }$ & - & $\sqrt{ }$ & - & $\sqrt{ }$ & T. harzianum \\
\hline 17 & PB 19 & $\sqrt{ }$ & - & $\sqrt{ }$ & - & $\sqrt{ }$ & T. harzianum \\
\hline 18 & PB 20 & $\sqrt{ }$ & - & $\sqrt{ }$ & - & - & T. harzianum \\
\hline 19 & PB 21 & $\sqrt{ }$ & - & $\sqrt{ }$ & - & $\sqrt{ }$ & T. harzianum \\
\hline 20 & PB 22 & $\sqrt{ }$ & - & $\sqrt{ }$ & - & - & T. harzianum \\
\hline 21 & PB 24 & $\sqrt{ }$ & - & $\sqrt{ }$ & - & $\sqrt{ }$ & T. harzianum \\
\hline 22 & PB 25 & $\sqrt{ }$ & - & $\sqrt{ }$ & - & $\sqrt{ }$ & T. harzianum \\
\hline 23 & PB 29 & $\sqrt{ }$ & - & $\sqrt{ }$ & - & $\sqrt{ }$ & T. harzianum \\
\hline 24 & PB 30 & $\sqrt{ }$ & - & $\sqrt{ }$ & - & - & T. harzianum \\
\hline 25 & PB 10 & - & $\sqrt{ }$ & - & $\sqrt{ }$ & $\sqrt{ }$ & T. virens \\
\hline 26 & PB 13 & - & $\sqrt{ }$ & - & $\sqrt{ }$ & $\sqrt{ }$ & T. virens \\
\hline 27 & PB 23 & - & $\sqrt{ }$ & - & $\sqrt{ }$ & - & T. virens \\
\hline 28 & PB 26 & - & $\sqrt{ }$ & - & $\sqrt{ }$ & $\sqrt{ }$ & T. virens \\
\hline 29 & PB 27 & - & $\sqrt{ }$ & - & $\sqrt{ }$ & $\sqrt{ }$ & T. virens \\
\hline 30 & PB 28 & - & $\sqrt{ }$ & - & $\sqrt{ }$ & - & T. virens \\
\hline
\end{tabular}

\section{DISCUSSION}

Cultural and morphological characterization: Cultural characteristics comprising growth rate, colony colour and colony appearance were regarded as taxonomically useful characteristics for Trichoderma (Samuels et al., 2002a). Studies revealed that all thirty rhizospheric isolates did not much differ in cultural characteristics with most isolates exhibiting rapid growth, effuse conidiation and/or loosely arranged conidia in pustules. The same findings like pale or yellowish colour of reverse of colonies, rapid growth at $25^{\circ} \mathrm{C}$ to $30^{\circ} \mathrm{C}$ of majority of Trichoderma isolates and typically not growing at $35^{\circ} \mathrm{C}$ were recorded by Samuels et al. (2002a). Gams and Bissett (2002), Lin and Heitman (2005) and Samuels et al. (2002a) also confirmed the presence of terminal and/or intercalary chlamydospores in cultures.

Morphological characterization was conventionally used in the identification of Trichoderma species, and it remains as a potential method to identify Trichoderma species (Anees et al., 2010; Gams and Bissett 2002; Samuels et al., 2002a). On the basis of description and keys given by Gams and Bissett (1998), Trichoderma isolates could be classified here into two groups as Trichoderma harzianum (80\%), Trichoderma virens (20\%). However, in the present study, the emphasis was given on conidiophores spread type i.e. gathering or non-gathering type and phialides type fertile or non-fertile (Gams and Bissett, 1998 and 2002; Rahman et al., 2011). Morphological study revealed two types 
of arrangement of conidiophores and phialides within 30 isolates. Conidiophores of the first group of 24 isolates were spread to the top and smooth or rounded, wide near the base. Phialides were arising mostly in crowded but had an angle with conidiophore, and had whorls of $2 \sim 6$ on the terminal branches. Conidia subglobose to ellipsoidal, apex broadly rounded, base more narrowly rounded (Samuels et al., 2002). These characteristics of the species $T$. harzianum sect. Pachybasium were same as described by Bisset (1991a, b). More than ever, second group of 6 isolates (PB 10, 13, 23, 26, 27 and 28) was characterized by predominant conidiation, many divided branches, gathering all finger to top, and fertile to the apex that was penicillate type. Conidiophores of $T$. virens were smoothly bent, gather and not spread to top. Conidia broadly rounded to obovoid, both ends broadly rounded or with the base narrower. Phialides were hung like banana in the conidiophore, base and apex were more narrow than middle. All these descriptions are in agreement with the findings of earlier investigators (Bisset, 1991a and b, Samuals et al., 1996, Gams and Bissett, 1998 and 2002, Samuels et al., 2002, Samuels et al., 2002a, Choi et al., 2003, and Shah et al., 2012 who recorded the similar observations.

\section{Conclusion}

Our study conclude that out of thirty isolates, 6 isolates namely PB10, PB13, PB23, PB26, PB27 and PB28 were identified as $T$. virens and remaining 24 isolates as $T$. harzianum on the basis of morphological characteristics. The cultural characteristics were not highly variable. Isolates except PB 12 and PB 20 showed fast growth reaching a radius of $50.3 \mathrm{~mm}$ to $56.5 \mathrm{~mm}$ after 72 hours at $25^{\circ} \mathrm{C}$ and conidiation was predominantly effuse.

\section{REFERENCES}

Anees, M., Tronsmo, A., Edel-Hermann, V., Gordon, H.L., Héraud, C. and Steinberg, C. (2010). Characterization of field isolates of Trichoderma antagonistic against Rhizoctonia solani. Fungal Biol., 114:691-701.

Bisset, J. (1991c). A revision of the genus Trichoderma. IV Additional notes on section Longibrachitum. Canadian Journal of Botany. 69: 2418-2420.

Bisset, J. (1991a). A revision of the genus Trichoderma. II. Infrageneric classification. Canadian Journal of Botany. 69: 2357-2372.

Bisset, J. (1991b). A revision of the genus Trichoderma. III.
Section Pachybasium. Canadian Journal of Botany. 69: 2373-2417.

Choi, In-Young, Seung-Beom Hong and Yadav, M.C. (2003). Molecular and morphological characterization of green mold, Trichoderma spp. isolated from oyster mushrooms. Mycobiology, 31(2): 74-80.

Elad, Y., Chet, L. and Henis, Y. (1981). A selective medium for improving quantitative isolation of Trichoderma spp. from soil. Phytoparasitica, 9 (1): 59-67.

Gams, W. and Bissett, J. (1998). Morphology and Identification of Trichoderma. In: Trichoderma and Gliocladium, Basic Biology, Taxonomy and Genetics, Harman, G.E. and C.P. Kubicek (Eds.). Vol. 1, Taylor and Francis, London, UK., pp: 3-34.

Gams, W. and Bissett, J. (2002). Morphology and identification of Trichoderma. In: Kubicek, C.P. and Harman, G.E. (eds.). Trichoderma and Gliocladium: Basic biology, taxonomy and genetics. Taylor \& Francis Ltd, pp. 3-31.

Krassilnikov, N.A. (1950). Actinomycetes-antagonists and antibiotic substances (in Russian). Academy of Sciences, U.S.S.R., Mascow, Leningrad.

Lin, X. and Heitman, J. (2005). Chlamydospore formation during hyphal growth in Cryptococcus neoformans. Eukaryotic Cell, 4: 1746-1754.

Rahman, A., Begum, M.F., Rahman, M., Bari, M.A., Ilias, G.N.M. and Alam, M.F. (2011). Isolation and identification of Trichoderma species from different habitats and their use for bioconversion of solid waste. Turk. J. Biol., 35:183-194.

Rifai, M.A. (1969). A revision of the genus Trichoderma. Mycological Papers. 116: 1-56.

Samuels, G.J., Petrini, O. and Manguin, S. (1996). Trichoderma: a review of biology and systematic of the genus. Mycol. Res., 100: 923-935.

Samuels, G.J., Chaverri, P., Farr, D.F. and McCray, E.B. (2002a). Trichoderma Online. Systematic Mycology and Microbiology Laboratory, ARS, USDA; Retrieved 24, August 2014 from http://nt.ars-grin.gov/ taxadescriptions/keys/TrichodermaIndex.cfm

Samuels, G.J., Dodd, S.L., Gams, W., Castleburry, L.A. and Petrini, O. (2002). Trichoderma species associated with the green mold epidemic of commercially grown Agaricus bisporus. Mycologia, 94: 146-170.

Seaby, D. (1996). Differentiation of Trichoderma taxa associated with mushroom production. Plant Pathol., 45: 905-912.

Shah, S., Nasreen, S. and Sheikh, P.A. (2012). Cultural and morphological characterization of Trichoderma spp. associated with green mold disease of Pleurotus spp. in Kashmir. Research Journal of Microbiology, 7: 139-144.

Singh, S.K., Sharma, V.P., Sharma, S.R., Kumar, S. and Tiwari, M. (2006). Molecular characterization of Trichoderma taxa causing green mould disease in edible mushrooms. Current Science, 90 (3): 427-431. 